\title{
Price Fluctuations of Rice Crop in District Sheikhupura
}

\author{
Wardah Qamar \\ Assistant Research Officer. (FM\& FE). Adaptive Research Farm, Sheikhupura, Punjab, \\ Pakistan
}

Muhammad Younas

Research Officer (M\&E) Punjab Agriculture Research Board, Lahore, Pakistan

Muhammad Waseem (Corresponding author)

College of Economics and Management, No. 1 Shizishan Street, Hongshan District, Huazhong Agricultural University, Wuhan (430070), China

Received: July 28, 2019

Accepted: August 19, 2019

Published: August 21, 2019

doi:10.5296/jas.v7i3.15163

URL: https://doi.org/10.5296/jas.v7i3.15163

\begin{abstract}
This research was done to explore the trends by using variables basmati prices, area in which rice were sown, coarse varieties area, coarse varieties' area and coarse varieties prices respectively to estimate the yield and productivity of basmati rice. According to the results of three models it was estimated that the price of basmati prices had a positive and significant effect on yield. The probability value showed the positive and significant effect on yield. Similarly, the area in which basmati sown had both significant and insignificant effect; the probability value of area sown in second models suggested the insignificant effect on yield. Another variable coarse variety area had a positive and significant effect on yield on all the three models that means this variable positively and significantly affecting the yield of basmati over the selected time. The variable of coarse varieties prices also had significant and insignificant effect, according to the probability value of this variable in third model the effect is positive but insignificant but other remaining two models are positive and significant. The last variable used i.e. coarse varieties prices had also positive and significant effect in all the three models, so it was estimated that this variable is positively affecting the yield of basmati rice. The Durbin Watson results showed that in first two models there is no autocorrelation because the value is in between 1.7 to 2.3 but in third model the value of Durbin Watson is not in the limit so it had autocorrelation among variables.
\end{abstract}

Keywords: price fluctuation, basmati rice, coarse variety, Sheikhupura 


\section{Introduction}

Agriculture is a main segment of the economic action and plays a vital role in the country's economic progress by providing raw materials, employment and food to a great amount of the people. While agriculture retains a significant place in Pakistan's economy, its effectiveness continued at a small level. The economy of Pakistan demonstrations a wide change but it is a fact that agriculture is still the chief sector. Its significance is clear from its influence of 42.3 percent to the total labor force, a major source of foreign exchange earnings and 19.5 percent to GDP. It is not first a base for the sugar industries and textile as well as provides the industrial sector with a raw material. It provides a market for developed products. So, any development in the agricultural sector has a long-lasting influence on the general growth of the country's GDP (GOP, 2017).

The overall economic performance of the country largely depends on the economic performance of agricultural sector. The rate of economic growth of Pakistan is affected by whatever happens to its agriculture. Past experiences show that the periods of high/low economic growth of national economy generally coincide with the trends in the growth of agricultural sector of Pakistan (Ali et al, 2007). Pakistan's total geographical area is 79.61 million hectares while the total reported area is 57.76 million hectares. Of this, 4.27 million hectares is forest area, 23.14 is not available for cultivation and 22.45 million hectares is used for crop production. The total irrigated area by different irrigation sources is 18.86 million hectares while the remaining area is under dry farming (GOP, 2014). Despite the significant contribution to GDP, Pakistan's agriculture sector has significantly lost its growth impetus in the last decade. The overall growth in agriculture has been declining since the decade of 1980's when it was 5.4 percent which turned down to 4.4 percent in the decade of 1990's and even slower in the decade of 2000's in which it was averaged to only 2.4 percent.

Rice is the seed of the monocot plants Oryza sativa (Asian rice) or Oryza glaberrima (African rice). As a cereal grain, it is the most widely consumed staple food for a large part of the world's human population. It is the agricultural commodity with the third-highest worldwide production, after sugarcane and maize (FAO, 2012).

Commodity prices are generally volatile and agricultural commodity prices are typically more volatile than those for example, of metals (Pindyck, 2004). High volatility poses difficulties in the prediction of agricultural commodity price changes which might exert large impacts on developing economies relying on the agricultural production, export and import of food commodities. Price risk raises problems for the macroeconomic as well as the microeconomic policy (Stigler, 2011).

Rice is an important food in the world. It is a staple food of more than 50 percent world's population and 75 percent of poor population. It is vital grain for human nourishment and caloric intake, providing more than one fifth of calories exhausted worldwide by people. Rice represents more than 20 percent of calories worldwide and 29 percent among low income countries (FAO, 2014).

Rice is an important cash crop that plays significant role in uplifting the nation's economy. It contributes 6798 thousand tones in our food. In Pakistan, it is a second staple food after wheat, 
and also chief source of foreign exchange income in crops after cotton. During 2016-17, rice crop was sown on area of 2724 thousand hectares showing a decrease of 0.6 percent over the last year's area of 2793 thousand hectares. Rice production stood at 6849 thousand tonnes achieving its targeted production of 6838 thousand tonnes and showing an increase of 0.7 percent over corresponding period of last year's production of 6801 thousand tonnes. Because of increase in business sector costs got amid a year ago, agriculturists takes all the more under development. Generation get to be expanded because of expansion in territory yet yield remained not critical because of surge/extreme downpours and illness assault (GOP, 2016-17).

Rice is also important source of foreign exchange after the wheat and cotton. It accounts 3.0 per cent of value added in agriculture and 0.6 per cent of GDP. During the month of March 2013-2014 USA $\$ 1.667$ billion foreign exchange is earned from rice. Rice cultivated an area of 2724 thousand hectares in year 2017 as it was cultivated 2792 thousand hector in last year. Production was stood at 6849 thousands tones against the target of 6838 thousands hectors it shows growth of 0.7 per cent against last year (GOP, 2016-17).

Area, yield and production of rice was different in different time period. In 2011, change in area was -18 percent, -29.9 percent production and yield change was -14.6. In 2012,8.7 percent change was in area, production was 27.7, and yield changes by 17.5 percent. In 2013 percentage change difference in area was-10.2, production change was -10.1 percent and yield change percentage was - 0.1 percent in yield. In 2014 percentage change in area was 20.8, production variation in production was 22.8 and yield variation was 1.6 percent. In 2015, percentage change in area was 3.7 percent, production change was 3.0 and yield was -0.6 . In 2016-17 percentage change in area was -0.6 , production variation was 0.7 and yield change percentage was 1.2 (GOP, 2016-17).

Rice producers in Pakistan sow several rice varieties. When deciding to diversify their farm acreage. Recommended rice varieties can differ in many aspects which ultimately influence costs and returns, such as seedling vigor, disease resistance, milling quality and yield potential. Annual production of coarse is 1237.6 thousand tones in Pakistan it is cultivated on area of 517.8 thousand hectares. According to drift of area and production of different paddy varieties in Punjab is not satisfactory because of increasing share of unapproved varieties. KSK-282 variety of coarse rice produced the highest paddy yield as compared to IRRI-6 and NIAB IRRI-9 when planted during second week of June under direct wet seeded culture. Although basmati rice varieties are dominant in Punjab but some coarse varieties are also being grown by the farmers (Hayat et al., 2003). Basmati varieties have long duration and late maturity while coarse varieties have short duration, early maturity and better resistance against pests and diseases (Ghazanfar et al., 2013).

Rice as being staple crop of Pakistan and population is increasing rapidly with each passing day which continues to pressurize the meager food supplies of the country. Its importance can be judged by the fact that it has a share of 3.2 percent to processed in agriculture along with 0.7 percent to gross domestic production. During 2016-17, sown on an area of 9052 thousand hectares witnessing a decrease of 1.9 percent compared to 9224 thousand hectares during same period last year. (GOP, 2016-17). 


\section{Review of Literature}

Haji (2006) estimated technical, allocative and economic efficiency of smallholder's vegetable growers in Ethiopia by using non-parametric data envelopment analysis method. The mean technical, allocative and economic efficiency was 91, 60 and 56 percent, respectively. It was found that assets, off farm income, farm size, extension visits and family size were the significant determinants of technical efficiency. The author concluded that assets, crop diversification, consumption expenditures and farm size had significant impact on allocative and economic efficiencies.

Villano and Fleming (2006) analyzed technical inefficiency of rice farmers in a rain fed lowland rice environment in Central Luzon, Philippines by using a stochastic frontier production function with a heteroskedastic error structure. An 8 years panel data set collected from 46 rain fed rice farmers was used. The average technical efficiency over the whole period was estimated at 79 percent, ranging from 10.7 to 98.8 percent. The highest estimated technical efficiency was in 1992 and the lowest was in 1996. It was found that the one-third farmers had a mean technical efficiency in the range of 0.81-0.90, one-quarter had a mean technical efficiency above 0.90 and 17 percent had a mean technical efficiency in the range of 0.71-0.80. The authors concluded that larger farmers were technically more efficient than the smaller farmers. Area planted to rice, labour and the amount of fertilizer used were found to be risk-increasing inputs whereas herbicide was found to be a risk-reducing input.

Breazeale et al. (2007) argued that due to increased competition for limited water resources in Oman, crop profitability was now becoming more important and was receiving more attention, especially in the case of high-water-use crops such as Rhodes grass. As Rhodes grass production in the Al-Batinah region requires significant water, production of Rhodes grass was being held responsible for over-capacity water pumping, resulting in salt water intrusion into coastal aquifers. There was little documented information in Oman related to Rhodes grass profitability. This study found that while Rhodes grass is marginally profitable, given current yields and output prices, even small price increases for such inputs as irrigation would quickly create negative returns for producers. Therefore, the long term sustainability of Rhodes grass production in the AlBatinah region appears to be pessimistic.

Idiong (2007) investigated farm level efficiency of 112 small-scale swamp rice farmers in Cross River State of Nigeria. The author estimated a stochastic production frontier that incorporated inefficiency factors by using a maximum likelihood (ML) procedure. Results of the study showed that the mean technical efficiency of small scale rice farmers was 77 percent, with a lowest of 48 and a highest of 99 percent. The author concluded that farmer's educational level, membership of cooperative/farmer association and access to credit were significantly and positively associated with the efficiency of small-scale swamp rice farmers in Nigeria.

Ogunniyi (2008) employed a trans-log stochastic frontier approach to examine the profit efficiency of cocoyam production in Osun State of Nigeria. Farm-level data were collected from a random sample of 180 farmers. The average efficiency level was 13 percent. The result from the trans-log frontier model showed that the dummy variable for soil was 
important factor explaining changes in returns. The results also revealed that family size, size of farm and credit contributed positively in gain of profit while farming experience effects negatively to profit. Gain of profit in cocoyam production could be increased significantly by increasing land holdings, by applying of mulch and to made better access of credit.

Giraud (2008) studied the rice varieties of Punjab, Pakistan. Basmati was found as the well renowned variety due to its most aromatic rice over the world. Populated urban markets were prone to accept a premium to Basmati, whom price was the highest for rice on trade and domestic markets. Punjab province represents 90 percent of overall Basmati rice production in Pakistan since immemorial times. This area forms the genuine alluvial lands appropriate for Basmati cultivation. Due to its price premium, some opportunist behaviors appear such as cropping blending of polished long grain from other varieties. The need of protection was clearly documented, but the registration of a Geographical Indication, will probably increase Basmati market shortages.

Sirirat et al. (2009) worked on efficiency improvement of rice farming in Thailand. Study quantified the technical inefficient frontier of rice farmers by applying input-oriented data analysis. The frontier approach represented the minimum level of inefficiency of inputs at the current level of yields, new technologies and managerial characteristics among the peasant farmers, which can be used as basic factor for inefficiency improvement in rice farms. Two-stage data envelopment analysis of inefficiency analysis was applied. The study results suggested the improvement measures for technical inefficiency of rice farmers in Thailand through the reduced usage of inputs.

Kiatpathomchai (2009) configured the technically efficient production frontier of rice farmers by applying the data envelopment analysis. The frontier assumed to have the maximum applicable level of inefficiency of the inputs under the current levels of output and managerial ability among the sampled farmers. A multi-stage DEA approach of efficiency analysis was used. The simple results showed that the technical inefficiency of rice farmers in southern areas of Thailand could be increased by decreasing the inputs level by 6-16 percent and the optimum output at 4.5 tons of rice per hectare could be achieved. The results from the study revealed some of precautionary measures which focused on adopting existing technologies.

Ayinde et al. (2009) argued in determinants of efficiency, that there were technical inefficiencies among the different categories of Nigerian rice farmers. By applying the meta-frontier approach made the technical inefficiency had the score value of 16 percent of the coefficient of the (VTGR), this revealed the difference in technical inefficiency between farmers that were cultivating the different varieties. The observation indicated higher variations among the sum of rice varieties and required the application of frontier models. Hence the new varieties had the ability to rise up the inefficiency of farmers in rice production. The average land size, fertilizers, seed, respondent's age, household size and access to credit were the statistically significant determinants of technical efficiency of farmers in Nigeria.

Sekhon et al. (2010) described the technical efficiency in crop production; a region wise analysis. It was concluded that even in a developed agricultural area such as in Punjab, the improvement in the technical efficiency of most of the farms was necessary. The farm 
specific characteristics showed the lower crop returns, lowest usage of fertilizers and machine power in small sized land holders. The higher net returns from the growing crops have been considered in the main areas. In the western area the usage of fertilizers and machinery power was larger. The overall average technical inefficiency had been estimated as 24 percent. Mean of the technical efficiency was recorded as to vary across the area; the most technically efficient area was considered in central region.

Kuosmanen et al. (2010) conducted the study on profit efficiency at the industry levels by excluding the price information completely. Two new suggestions were made. Firstly, the profit efficiency was estimated in monetary form by applying the shadow prices as well. Second was that, all of the firms having the same prices was configured. That was permitted to firm profit efficiencies to the overall industry efficiency. In the presence of profit losses as costs, the presented study results helps one to get all about price information from the available data. A series of data set from the Monte Carlo aggregations was confined and applied to study to improve the overall performance of the model in production environment conditions under control.

Khan et al. (2010) examined the effects of input prices on the crop production inefficiencies, by using the secondary type of data. The factors that were analyzed included productivity behavior, optimal applications of fertilizers and their impacts on the production of different crops. The results also showed that the farmers who used the fertilizers had higher productivity than that of other farms that did not applied this. The major part of the gains in production or yield was considered to be more balanced and optimal usage of fertilizers. The secondary data and a sample size of 15 were used in that study which years from 1992 to 2006 which ensures that the agricultural out-put was highly dependent on the optimal application of fertilizers and also the balanced fertilizer application highly depends on its price. The fertilizer's prices were going to be high due to recent crises as that were highly energy and gas intensive. The results suggested that productivity in agricultural enterprise would be increased by reduction in input prices and their proper availability.

Singh and Sharma (2011) estimated the specific determinants of technical efficiency of dairy farms by applying the stochastic frontier production model, that was co-related a model for technical efficiency estimates having creativity of technology, financial status, age and number of schooling years on the productivity of the milk. Overall the mean of technical inefficiency would be one-third of the total selected sample. So, the total production of milk could be improved by two-third of the total in spite of using additional inputs. The results of the study further concluded that the technical inefficiency of producers of milk was negatively affected by the creativity, financial status; the age of the milk producers had negative impact as well. The lower financial status farmers with lower level of schooling years were observed as poor managers. The configured that to improve the young farmers and increasing their schooling years was necessary along the raising of the level of education.

Al Said et al. (2012) found that the Improving water productivity can make a sterling contribution to global food production and poverty alleviation. Groundwater has always been a critical resource for agriculture. Scientific understanding of water productivity can help address 
water scarcity concerns through more productive use of scarce water resources and higher socio-economic benefits from available water. This study examined the water productivity in the Al Batinah region of Oman using farm-level data. In total 124 crops grown during the 4 years 2005-2008 were examined. Field studies were carried out for 4 years (2005-2008) on 18 field plots to examine yield, inputs, irrigation, costs and economic return of sweet melon, sweet pepper, cabbage and tomatoes grown under drip irrigation vs. Rhodes grass grown under sprinkler irrigation using groundwater. The aim was to identify suitable combinations of vegetable crops grown under drip irrigation that can maximize the profitability of the farmers by optimizing water productivity. Results from the 4-year data show that tomato and cabbage performed better than sweet pepper or melon as far as water productivity was concerned, while the drip irrigation method had shown better performance than sprinkler irrigation.

Hussain (2013) undertook economic analysis of rice (Oryza sativa) crop cultivation in district Swat. Three tehsils namely Kabal, Matta and Barikot were selected on the basis of purposive sampling technique. From each tehsil, three villages were selected and seven rice varieties were grown. Primary data were collected from 100 respondents (farmers) randomly selected through structured questionnaire. Sample size was allocated to these nine villages on the basis of proportional allocation method. For data analysis, benefit cost ratios, log-linear Cobb-Douglas production function, Wald test and marginal rate of substitutions were estimated. According to the results maximum benefit cost ratio was noted for variety Fakhr-e-Malakand (3.41) followed by Basmati-385 (3.37). This indicates that Fakhr-e-Malakand was the most profitable variety of rice as compared to all other rice varieties. The output elasticities of area, tractor hours, fertilizer, seed, labour and pesticides were observed as $0.3112,0.0012,0.5924,0.6212,0.5124$ and 0.0013 , respectively. The input-output relationship holds increasing returns to scale. The farmers should be advised to cultivate high yielding varieties like Fakhr-e-Malakand and also use improved seed.

\section{Methodology}

\section{Study Area and Data Sources}

The study was conducted in Punjab, Pakistan. Punjab is the largest producer of agricultural commodities in Pakistan. There are about 5.5 million farms in Punjab which cover an area of 28.77 million acres (Naseer et al., 2016). Further, most farmers practice mixed cropping while producing crops and rearing dairy animals to meet their daily needs (Ashfaq et al., 2015a); Ashfaq et al. (2015b). Considering the importance of Punjab in Pakistan's agricultural economy, we purposively selected this province for estimating technical efficiency of wheat farmers. The data used in this study was obtained through field survey of 125 rice farmers from district Sheikhupura. This district represents a typical case study for Basmati rice production in Punjab which is famous all over the world for its taste and aromatic properties. The rice production in the district is on the reise since last two decades as more and more farmers and pledging area under rice production. The farmers were selected through a multistage random sampling procedure. The data was collected by the interviewers of Adaptive Research Farm, Sheikhupura. Farmers were ensured about the confidentiality and anonymity of the collected data. 
Estimating the Production Function for Rice Crop and the Cost of Rice Production in the District

Following equations and models were used to estimate the production function for rice, the cost of rice production, and other related variables of interest.

Output $=\beta 0+\beta 1(B P R)+\beta 2(B A S)+\beta 3(C V)+\beta 4(C V P)+\beta 5(C V Y)+\mu$

BPR=BASMATI_PRICES_RECEIVED; BAS =BASMATI_AREA_SOWN_BY_FAR

$\mathrm{CV}=\mathrm{COARSE}$ _VARITIES_AREA_SO; CVP =COARSE_VARITIES_PRICES_R

CVY $=$ COARSE_VARITIES_YIELD_PR

\section{Results and Discussion}

Cost of production related to super basmati is described in Table 1. This study tries to estimate the total financial cost of production of super Basmati (Rs/Acre). To estimate the total cost of production this analysis cover up some essential components which are the major determinant of rice production. These determinants explained the major cost which bears by a former. As highlighted in table 1; land preparation, seeding \& sowing, irrigation, fertilizer, FYM, chemical cost, total financial input cost, and harvesting \& threshing are the main determinants which estimate the cost of production. Estimated cost of production for one acre land preparation, seeding \& sowing, irrigation, fertilizer, FYM, chemical cost, total financial input cost and harvesting \& threshing was 4932.2, 1560, 9021.8, 8855.8, 5380, 1923.5, 31672.8 and 2979 respectively, while the total cost of production was estimated 34651.8 (Rs/Acre).

Table 1. Financial Cost of Production of Super Basmati (Rs/acre)

\begin{tabular}{c|c}
\hline Farm size categories & Total \\
\hline Land preparation & 4932.2 \\
\hline Seedling \& Sowing & 1560 \\
\hline Irrigation & 9021.8 \\
\hline Fertilizer & 8855.8 \\
\hline FYM & 5380 \\
\hline Chemical cost & 1923.5 \\
\hline Total financial input cost & 31672.8 \\
\hline Harvesting \& Threshing & 2979 \\
\hline The total financial cost of production & 34651.8 \\
\hline
\end{tabular}

As given in table 2; some variables added for a specific time which measured the cost of production related to super basmati per acre in rupees. Likewise the above table, this table also covers up some fundamental element which measured the cost of production. These elements are Land preparation, Seedling \& Sowing, Irrigation, Fertilizer, FYM, Chemical cost, Total Economic input cost, Mark upon investment, Harvesting \& Threshing, Land rent for six month, and Management charges, while estimated cost of each element is 5060.4, 
1590, 11245, 9201.6, 5435, 2260, 34792, 1175, 3145, 21302, and 900 respectively. Similarly, after the addition of all cost, this table predicted that the gross cost of production was 61314 (Rs/Acre).

Table 2. Economic Cost of Production of Super Basmati (Rs/acre)

\begin{tabular}{c|c}
\hline Farm size categories & Total \\
\hline Land preparation & 5060.4 \\
\hline Seedling \& Sowing & 1590 \\
\hline Irrigation & 11245 \\
\hline Fertilizer & 9201.6 \\
\hline FYM & 5435 \\
\hline Chemical cost & 2260 \\
\hline Total Economic input cost & 34792 \\
\hline Mark up on investment & 1175 \\
\hline Harvesting \& Threshing & 3145 \\
\hline Land rent for six month & 21302 \\
\hline Management charges & 900 \\
\hline Total economic cost of production & 61314 \\
\hline
\end{tabular}

\section{Results of the OLS Model}

The following estimates are generated by applying the OLS model to estimate the rice production function.

Model 1: Ordinary Least Square (OLS)

$$
\begin{gathered}
\text { Output }=5.991673+0.198(B P R)+0.111(B A S)+0.077(C V) \\
+0.344(C V P)+0.015(C V Y)+\mu
\end{gathered}
$$

Table 3. Results of OLS 2015-2016

\begin{tabular}{c|c|c|c|c}
\hline Variable & Coefficient & Std. Error & t-Statistic & Prob. \\
\hline BASMATI_PRICES_RECEIVED_ & 0.25858 & 0.05766 & 4.48784 & 0.0000 \\
\hline BASMATI_AREA_SOWN_BY_FAR & 0.26338 & 0.011111 & 23.7207 & 0.0025 \\
\hline COARSE_VARITIES_AREA_SO & 0.09832 & 0.072995 & 1.347044 & 0.0009 \\
\hline COARSE_VARITIES_PRICES_R & 0.26325 & 0.06010 & 4.38019 & 0.000 \\
\hline COARSE_VARITIES_YIELD_PR & 0.060254 & 0.108391 & 0.555893 & 0.0998 \\
\hline C & 0.514029 & 0.425017 & 1.209432 & 0.0000 \\
\hline R-squared (0.94) & $\begin{array}{c}\text { F-statistic } \\
(436.12)\end{array}$ & \multicolumn{3}{|c}{ Durbin Watson (2.334) } \\
\hline
\end{tabular}

The results suggested that $1 \%$ increase in basmati prices can increase the yield by $0.19 \%$ which has significant impact on the production of rice. Similarly, $1 \%$ increase in the area in which basmati sown increased the yield by $0.11 \%$ and was significant. The increase in $1 \%$ of coarse varieties area increased the yield by $0.07 \%$. Another $1 \%$ increase in coarse varieties 
prices increased the yield by $34 \%$ but was insignificant. The increase of $1 \%$ in coarse varieties increased the yield by $0.01 \%$. Durbin Watson result shows that there is no serial-correlation among variables. According to the value of Durbin Watson (2.597), this showed no serial-correlation among our concern variables. Similarly, the result of co-efficient of determination explained that the dependent variable is explained by independent variables with the percentage of 61 , while F-statistics explained about over all significance of model.

Model 2: Ordinary Least Square (OLS)

$$
\begin{gathered}
\text { Output }=24.23+0.284(B P R)+0.107(B A S)+0.041(C V)+0.596(C V P) \\
+0.080(C V Y)+\mu
\end{gathered}
$$

Table 4. Results of OLS 2014-2015

\begin{tabular}{c|c|c|c|c|c}
\hline Variable & & Coefficient & Std. Error & t-Statistic & Prob. \\
\hline BASMATI_PRICES_RECEIVED_ & & 0.28495 & 0.02389 & 11.9275 & 0.0000 \\
\hline BASMATI_AREA_SOWN_BY_FAR & & 0.10753 & 0.011287 & 9.53280 & 0.3426 \\
\hline COARSE_VARITIES_AREA_SO & & 0.041888 & 0.041437 & 1.010881 & 0.0653 \\
\hline COARSE_VARITIES_PRICES_R & & 0.59659 & 0.03088 & 19.3196 & 0.0000 \\
\hline COARSE_VARITIES_YIELD_PR & & 0.080517 & 0.096607 & 0.833449 & 0.0000 \\
\hline C & & 24.23181 & 4.202358 & 5.766241 & 0.0000 \\
\hline R-squared (0.67) & & $\begin{array}{c}\text { F-statistic } \\
(3.568)\end{array}$ & Durbin Watson (2.160) \\
\hline
\end{tabular}

The results suggested that $1 \%$ increase in basmati prices can increase the yield by $0.28 \%$ which has significant impact on the production of rice. Similarly, $1 \%$ increases in the area in which basmati sown increased the yield by $0.10 \%$ but was insignificant. The increase in $1 \%$ of coarse varieties area increased the yield by $0.04 \%$ and significant. Another $1 \%$ increase in coarse varieties prices increased the yield by $0.59 \%$ and was significant. The increase of $1 \%$ in coarse varieties increased the yield by $0.08 \%$. Durbin Watson result shows that there is no autocorrelation among variables. According to the value of Durbin Watson (2.160), this showed no serial-correlation among our concern variables. Similarly, the result of co-efficient of determination explained that the dependent variable is explained by independent variables with the percentage of 67 , while F-statistics explained about over all significance of model.

Model 3: Ordinary Least Square (OLS)

$$
\begin{gathered}
\text { Output }=0.514+0.258(B P R)+0.263(B A S)+0.098(C V)+0.263(C V P) \\
+0.060(C V Y)+\mu
\end{gathered}
$$


Table 5. Results of OLS 2013-2014

\begin{tabular}{c|c|c|c|c}
\hline Variable & Coefficient & Std. Error & t-Statistic & Prob. \\
\hline BASMATI_PRICES_RECEIVED_ & 0.19876 & 0.01465 & 13.56723 & 0.0000 \\
\hline BASMATI_AREA_SOWN_BY_FAR & 0.11195 & 0.021087 & 5.30834 & 0.0096 \\
\hline COARSE_VARITIES_AREA_SO & 0.077947 & 0.129750 & 0.600748 & 0.0051 \\
\hline COARSE_VARITIES_PRICES_R & 0.34455 & 0.08565 & 4.02276 & 0.6883 \\
\hline COARSE_VARITIES_YIELD_PR & 0.015892 & 0.122174 & 0.130073 & 0.0000 \\
\hline C & 5.991673 & 1.630767 & 3.674143 & 0.0004 \\
\hline R-squared (0.61) & $\begin{array}{c}\text { F-statistic } \\
(38.415)\end{array}$ & \multicolumn{3}{|c}{ Durbin Watson (2.597) } \\
\hline
\end{tabular}

The results suggested that $1 \%$ increase in basmati prices can increase the yield by $0.25 \%$ which has significant impact on the production of rice. Similarly, $1 \%$ increases in the area in which basmati sown increased the yield by $0.26 \%$. The increase in $1 \%$ of coarse varieties area increased the yield by $0.09 \%$. Another $1 \%$ increase in coarse varieties prices increased the yield by $0.26 \%$. The increase of $1 \%$ in coarse varieties increased the yield by $0.06 \%$ and all were significantly positive. According to the value of Durbin Watson (2.334), this showed no serial-correlation among our concern variables. Similarly, the result of co-efficient of determination explained that the dependent variable is explained by independent variables with the percentage of 94, while F-statistics explained about over all significance of model.

\section{Conclusion}

This research was done to explore the trends by using variables basmati prices, area in which rice were sown, coarse varieties area, coarse varieties' area and coarse varieties prices respectively to estimate the yield and productivity of basmati rice. According to the above results of three models it was estimated that the price of basmati prices had a positive and significant effect on yield. The probability value showed the positive and significant effect on yield. Similarly, the area in which basmati sown had both significant and insignificant effect; the probability value of area sown in second models suggested the insignificant effect on yield. Another variable coarse varieties area had a positive and significant effect on yield on all the three models that means this variable positively and significantly affecting the yield of basmati over the selected time. The variable of coarse varieties prices also had significant and insignificant effect, according to the probability value of this variable in third model the effect is positive but insignificant but other remaining two models are positive and significant. The last variable used i.e. coarse varieties prices had also positive and significant effect in all the three models so it was estimated that this variable is positively affecting the yield of basmati rice. The Durbin Watson results showed that in first two models there is no autocorrelation because the value is in between 1.7 to 2.3 but in third model the value of Durbin Watson is not in the limit so it had autocorrelation among variables. 


\section{References}

Ali, R. I., Awan, T. H., Manzoor, Z., Ashraf, M. M., Safdar, M. E., \& Ahmad, M. (2007). Screening of rice varieties suitable for direct seeding in Punjab. J. Anim. Pl. Sci, 17(1-2), 24-26.

Al-Said, F. A., Ashfaq, M., Al-Barhi, M., Hanjra, M. A., \& Khan, I. A. (2012). Water productivity of vegetables under modern irrigation methods in Oman. Irrigation and Drainage, 61(4), 477-489. https://doi.org/10.1002/ird.1644

Ayinde, O. E., Adewumi, M. O., \& Ojehomon, V. E. (2009). Determinants of technical efficiency and varietal-gap of rice production in Nigeria: a meta-frontier model approach (No. 1005-2016-79099, pp. 1-21).

Breazeale, D., Khan, I., Al-Saadi, N., \& Curtis, K. R. (2007). The Economics of Continuing Rhoades Grass Production Under Sprinkler Irrigation in the Al-Batinah Region of the Sultante of Oman. Journal of Applied Irrigation Science, 42(2), 119.

FAO. (2012). Planning for Effective Training: A Guide to Curriculum Development Food and agric. Organization, Rome, Italy.

Food and Agric. Organization, (2014). Statistical Year book of the Food and Agricultural Organization. FAO, Rome, Italy.

Giraud, G. (2008). Range and Limit of Geographical Indication Scheme: The Case of Basmati Rice from Punjab, Pakistan. International Food and Agribusiness Management Review, 11(1), 51-76.

Government of Pakistan (GOP). (2014). Economic Survey of Pakistan, 2011-12, Ministry of Finance, Islamabad. Available at: finance.gov.pk/survey_1314.html

Government of Pakistan (GOP). (2016-17). Agricultural Statistics of Pakistan, 2016-17, Pakistan Bureau of Statistics, Islamabad, Pakistan.

Haji, J. (2006). Production efficiency of small holder's vegetable dominated mixed farming system in Eastern Ethiopia: A non-parametric approach. Journal of African Economies, 16, 1-27. https://doi.org/10.1093/jae/ej1044

Hayat, M., Kazmi, I., Khaliq, T., Ahmad, A., Saleem, M. F., \& Shabbir, A. (2003). Variability in water use, crop water productivity and profitability of rice and wheat in Rechna doab, Punjab, Pakistan. The Journal of Animal and Plant Sciences, 22(4), 998-1003.

Hussain, A. (2013). Economic analysis of rice crop cultivation in district Swat. J. Agric. Res., 51(2), 175-189.

Idiong, I. C. (2007). Estimation of farm level technical efficiency in small scale swamp rice production in Cross River State of Nigeria: A stochastic frontier approach. World Journal of Agricultural Sciences, 3, 653-658.

Khan, H. G. A., Ahmad, A., \& Siraj, A. (2010). Impact of rising prices of fertilizers on crops 
production in Pakistan. Global Journal of Management And Business Research, 10(9).

Kiatpathomchai, S., Schmitz, P. M., \& Thongrak, S. (2009). Technical efficiency improvement of rice farming in southern Thailand (No. 1005-2016-79173).

Kuosmanen, T., Kortelainen, M., Sipilainen, T., \& Cherchye, L. (2010). Firm and industry level profit efficiency analysis using absolute and uniform shadow prices. European Journal of Operational Research, 202, 584-594. https://doi.org/10.1016/j.ejor.2009.06.002

Ogunniyi, L. T. (2008). Profit efficiency among cocoyam producers in Osun State, Nigeria. International Journal of Agricultural Economics and Rural Development, 1(1), 38-46.

Pindyck, R. S. (2004). Volatility and commodity price dynamics. Journal of Futures Markets: Futures, Options, and Other Derivative Products, 24(11), 1029-1047.

https://doi.org/10.1002/fut.20120

Sekhon, M. K., Mahal, A. K., Kaur, M., \& Sidhu, M. S. (2010). Technical efficiency in crop production: A region-wise analysis. Agricultural Economics Research Review, 23(347-2016-16932), 366-374.

Singh, S., \& Sharma, S. (2011). Measurement of Technical Efficiency in Dairy Sector of India: A Stochastic Frontier Production Function Approach. TMC Academic Journal, 5, 51-64.

Sirirat, K., Schmitz, P. M., \& Thongrak, S. (2009). Technical efficiency improvement of Rice farming in southern Thailand. Institute of agricultural policy and market research, Justus-liebig University Giessen, Germany.

Stigler, M. (2011). Commodity prices: theoretical and empirical properties. Safeguarding food security in volatile global markets, 27-44.

Villano, R., \& Fleming, E. (2006). Technical inefficiency and production risk in rice farming: Evidence from Central Luzon Philippines. Asian Economic Journal, 20, 29-46. https://doi.org/10.1111/j.1467-8381.2006.00223.x

\section{Copyright Disclaimer}

Copyright for this article is retained by the author(s), with first publication rights granted to the journal.

This is an open-access article distributed under the terms and conditions of the Creative Commons Attribution license (http://creativecommons.org/licenses/by/4.0/). 